\title{
A sintering-free, nanocrystalline tin oxide electron selective layer for organometal perovskite solar cells
}

\author{
Jinjin Zhao ${ }^{1,2,3 \dagger^{*}}$, Liyu Wei ${ }^{1 \dagger}$, Jinxi Liu ${ }^{1}$, Peng Wang ${ }^{1}$, Zhenghao Liu ${ }^{1,3}$, Chunmei Jia ${ }^{1}$ and Jiangyu Li ${ }^{2,33^{*}}$
}

\begin{abstract}
Effective electron selective layer (ESL) is critical for the power conversion efficiency in organometal halidebased perovskite solar cells (PSCs). In this work, a spincoating process has been developed to fabricate high quality nanocrystalline $\mathrm{SnO}_{2}$ film at $100^{\circ} \mathrm{C}$ without further sintering at higher temperature. When used as ESL in PSCs, such $\mathrm{SnO}_{2}$ film shows greater electron extraction ability and higher efficiency than $\mathrm{TiO}_{2}$ film processed under similar condition, as evidenced by the efficient time-resolved photoluminescence (TRPL) quenching $\mathrm{SnO}_{2} / \mathrm{CH}_{3} \mathrm{NH}_{3} \mathrm{PbI}_{3}$ film. As a result, the $\mathrm{SnO}_{2}$-based PSCs possess higher open circuit voltage of $0.91 \mathrm{~V}$, short circuit current density of $20.73 \mathrm{~mA} \mathrm{~cm}^{-2}$, and fill factor of $64.25 \%$, corresponding to a conversion efficiency of $12.10 \%$, compared with $7.16 \%$ of $\mathrm{TiO}_{2}$-based PSCs. This demonstrates the great potential of applying spin-coating sintering-free process for the low-cost and large-scale manufacturing of PSCs.
\end{abstract}

Keywords: low-temperature, sintering-free, perovskite solar cells, $\mathrm{SnO}_{2}$, electron-selective layer

\section{INTRODUCTION}

Recent progress in perovskite solar cells (PSCs) has attracted great attention due to the rapid improvement of their power conversion efficiency (PCE) from initial $3.8 \%$ in 2009 to certified $22.1 \%$ in 2016 [1-9]. Selective extraction of photo-generated electrons and holes that inhibits charge recombination is necessary for achieving high efficiency in PSCs [10], and the exploration of the effective electron selective layer (ESL) remains a challenging scientific issue. While many semiconductors are feasible as ESL materials for PSCs, the majority of the studies focus on $\mathrm{TiO}_{2}$ and $\mathrm{ZnO}$ [11-18]. Compared with $\mathrm{TiO}_{2}$ and $\mathrm{ZnO}$, $\mathrm{SnO}_{2}$ not only has much higher electron mobility but also a wider band gap [19-22], and thus has a smaller ESL-induced current absorption loss, and is more stable under UV illumination [23-25]. Moreover, it has been reported that improved hysteretic behaviour and high efficiencies can be achieved using $\mathrm{SnO}_{2}$ nanocrystals in planar PSCs $[22,26,27]$. In such configuration, the relative energy levels of the solar cell components are shown in Fig. 1. Free charge carriers are generated in the $\mathrm{CH}_{3} \mathrm{NH}_{3} \mathrm{PbI}_{3}$ layer with direct band gap and high carrier mobility, which are then extracted by the $\mathrm{SnO}_{2}$ ESL and the spiro-OMeTAD hole transport materials (HTM), respectively. Given the highly selective properties of both $\mathrm{SnO}_{2}$ ESL and spiro-OMeTAD HTM, high efficient devices with improved fill factors are expected.

Generally, materials processed at higher temperatures will exhibit higher charge carrier mobility due to better crystallinity, and thus in order to achieve high device performance, the solution-processed compact $\mathrm{SnO}_{2}$ ESL normally requires a high temperature sintering procedure at $450^{\circ} \mathrm{C}$ [28]. In previous studies, attempts have been made to decrease the processing temperature of $\mathrm{SnO}_{2}$ to $180^{\circ} \mathrm{C}$ on the fluorine doped tin oxide (FTO) glass $[2,29]$, and to $150^{\circ} \mathrm{C}$ for $\mathrm{SnO}_{2}$ nanocrystalline film with particle size of 22-43 nm [30]. Liu et al. [31] reported an even lower processing temperature of $140^{\circ} \mathrm{C}$ to achieve an effective electron selection and a high PCE greater than $15 \%$. Nevertheless, for the facile fabrication of the low-cost and large-scale planar perovskite solar cells, it is desirable to develop a compact $\mathrm{SnO}_{2}$ film with good crystallinity and small particle size under even lower-temperature annealing.

In this work, the highly crystalline homogeneous $\mathrm{SnO}_{2}$

\footnotetext{
${ }^{1}$ School of Materials Science and Engineering, Department of Engineering Mechanics, Shijiazhuang Tiedao University, Shijiazhuang 050043, China

${ }^{2}$ Department of Mechanical Engineering, University of Washington, Seattle, 98195-2600, USA

${ }^{3}$ Shenzhen Key Laboratory of Nanobiomechanics, Shenzhen Institutes of Advanced Technology, Chinese Academy of Sciences, Shenzhen 518055, China

These authors contributed equally to this work.

*Corresponding authors (emails: jinjinzhao2012@163.com (Zhao J); jjli@uw.edu (Li J))
} 

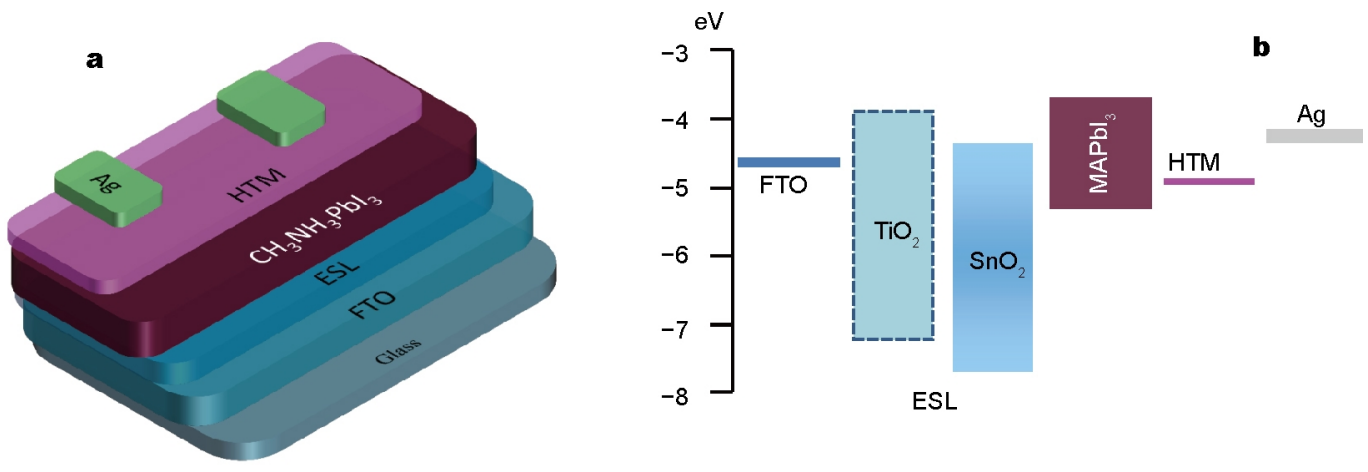

Figure 1 (a) Device architecture of the FTO/ESL $\left(\mathrm{SnO}_{2}\right) / \mathrm{CH}_{3} \mathrm{NH}_{3} \mathrm{PbI}_{3} /$ spiro-OMeTAD/Ag cells; (b) energy levels (relative to vacuum) of the various device components.

film was fabricated using a spin-coating and sintering-free method with film processing temperature at only $100^{\circ} \mathrm{C}$. The $\mathrm{SnO}_{2}$ film displays complete surface coverage, uniform nanocrystals size of 2-5 $\mathrm{nm}$ and great electron extraction ability, as evidenced by the efficient time-resolved photoluminescence (TRPL) quenching of $\mathrm{SnO}_{2} / \mathrm{CH}_{3} \mathrm{NH}_{3} \mathrm{PbI}_{3}$ film. Furthermore, a conversion efficiency of $12.10 \%$ is achieved in PSCs based on $\mathrm{SnO}_{2}$ ESL processed as such, much higher than $7.16 \%$ of PSCs based on $\mathrm{TiO}_{2}$ ESL processed in a similar manner.

\section{EXPERIMENTAL}

\section{Raw materials}

$\mathrm{PbI}_{2}$ (99.99\%) and N,N-dimethylformide (DMF) were purchased from Sigma-Aldrich and Alfa Aesar, respectively. $\quad \mathrm{CH}_{3} \mathrm{NH}_{3} \mathrm{I}(>99.0 \%)$ was purchased from Xian Polymer Light Technology Co. 2,2',7,7'-tetrakis( $N, N$-di- $p$-methoxyphenylamine)-9,9'-spirobifluorene (spiro-OMeTAD) ( $\geq 99.0 \%$ ) was purchased from Shenzhen Feiming Science and Technology Co., Ltd. FTO glass with a sheet resistance of $14 \mathrm{ohm} / \mathrm{square}$ was purchased from Pilkington Glass. Pluronic F127 was purchased from Sigma-Aldrich, Inc. The purity of silver wire, purchased from Nanchang Guocai Technology Co., is 99.99\%. All other materials were purchased from J\&K Scientific Ltd. All of the used reagents were analytical grade.

\section{Preparation of $\mathrm{SnO}_{2}$ nanocrystals}

Firstly, $0.1 \mathrm{~mol} \mathrm{~L}^{-1} \mathrm{SnCl}_{4}$ was dissolved into $100 \mathrm{~mL}$ ethanol, and then $100 \mathrm{~mL} \mathrm{NaOH}$ solution $\left(1 \mathrm{~mol} \mathrm{~L}^{-1}\right)$ was dropped to the above solution. After stirring for $15 \mathrm{~min}$, a white milky solution was obtained. Secondly, the white colloidal deposition was centrifuged and washed with ethanol twice, and dried at $80^{\circ} \mathrm{C}$ for $10 \mathrm{~h}$ in vacuum, and then calcined at $400^{\circ} \mathrm{C}$ for $1 \mathrm{~h}$ to obtain a snow white $\mathrm{SnO}_{2}$ powder.

\section{Spin-coating of $\mathrm{SnO}_{2}$ ESL films}

The prepared $\mathrm{SnO}_{2}$ nanocrystals were spin-coated on the transparent and conductive FTO substrate as following. Firstly, FTO-coated glass substrates were cleaned by ultrasonication in an alkaline, aqueous washing solution, and rinsed with deionized water, ethanol, acetone and 2-propanol, respectively. Then the $\mathrm{SnO}_{2}$ nanoparticles were dispersed in ethanol at a concentration of $5 \mathrm{mg} \mathrm{mL}^{-1}$ and stirred for $24 \mathrm{~h}$ before use. Finally, the solution was filtered with a $0.45 \mu \mathrm{m}$ filter and spin-coated on FTO substrates at $3000 \mathrm{rpm}$ for $30 \mathrm{~s}$ to form a $\mathrm{SnO}_{2}$ layer, followed by short drying at $100^{\circ} \mathrm{C}$ for $10 \mathrm{~min}$, without further calcination or sintering.

\section{Fabrication of $\mathrm{TiO}_{2}$ nanocrystals and ESL films}

For comparison, ESL made of $\mathrm{TiO}_{2}$ nanoparticles was also prepared. $\mathrm{TiO}_{2}$ nanoparticles were fabricated first as following [32]. Pluronic F127 (2.97 g) was dissolved in 36.88 $\mathrm{g}$ ethanol at $40^{\circ} \mathrm{C}$ for $30 \mathrm{~min}$ to form a clear solution, after which $3.4 \mathrm{~g} \mathrm{TiCl}_{4}$ was added to the solution. The precursor solution was then poured into a Teflon-lined stainless steel autoclave and stirred for $8 \mathrm{~h}$ under $40^{\circ} \mathrm{C}$. The autoclave was heated in an oven at $160^{\circ} \mathrm{C}$ for $16 \mathrm{~h}$. Subsequently, the products in autoclave were filtered, washed and dried at $80^{\circ} \mathrm{C}$. The powders were then calcined at $610^{\circ} \mathrm{C}$ for 10 min after being kept at $300^{\circ} \mathrm{C}$ for $1.5 \mathrm{~h}$ and $500^{\circ} \mathrm{C}$ for $4 \mathrm{~h}$. During the whole process, the heating rate was kept at $2^{\circ} \mathrm{C}$ $\mathrm{min}^{-1}$. After sintering, the products were dispersed using deionized water and nitric acid (65\%) until the $\mathrm{pH}$ of the solution reached about 2 . Then the mixture solution was vigorously stirred at $80^{\circ} \mathrm{C}$ for $8 \mathrm{~h}$ to obtain $\mathrm{TiO}_{2}$ nanoparticles, which were subsequently dispersed in ethanol at $5 \mathrm{mg}$ $\mathrm{mL}^{-1}$ and stirred for $24 \mathrm{~h}$ before use. Finally, the suspension 
solution was filtered with a $0.45 \mu \mathrm{m}$ filter and spin-coated on FTO substrates at $3000 \mathrm{rpm}$ for $30 \mathrm{~s}$ to form a $\mathrm{TiO}_{2}$ layer, followed by short drying at $100^{\circ} \mathrm{C}$ for $10 \mathrm{~min}$, without sintering at high temperature.

\section{Fabrication of perovskite solar cells}

The $\mathrm{CH}_{3} \mathrm{NH}_{3} \mathrm{PbI}_{3}$ layer was grown on ESL using a two-step solution process. To ensure the selective collection of electrons at the FTO electrodes, the perovskite layer was deposited on the n-type compact $\mathrm{SnO}_{2}$ or $\mathrm{TiO}_{2} \mathrm{ESL}$, followed by deposition of spiro-OMeTAD as the p-type hole conducting layer. Finally the Ag layer was evaporated.

The procedure for preparation of $\mathrm{CH}_{3} \mathrm{NH}_{3} \mathrm{PbI}_{3}$ film on ESL was as follows: $\mathrm{PbI}_{2}$ was dissolved in DMF at a concentration of $462 \mathrm{mg} \mathrm{mL}^{-1}\left(\sim 1 \mathrm{~mol} \mathrm{~L}^{-1}\right)$ under mild stirring speed of $200 \mathrm{rpm}$ at $70^{\circ} \mathrm{C}$. The solution was kept at $70^{\circ} \mathrm{C}$ during the whole procedure. The $\mathrm{PbI}_{2}$ film was spincoated onto ESL at $4500 \mathrm{rpm}$ for $30 \mathrm{~s}$ and dried. The films were then dipped in a solution of $\mathrm{CH}_{3} \mathrm{NH}_{3} \mathrm{I}$ in 2-propanol $\left(10 \mathrm{mg} \mathrm{mL}^{-1}\right)$ for $10 \mathrm{~min}$, rinsed with 2-propanol and dried at $70^{\circ} \mathrm{C}$ for $30 \mathrm{~min}$.

The HTM was then deposited by spin coating at 4000 rpm for $30 \mathrm{~s}$. The spin-coating formulation was prepared by dissolving $72.3 \mathrm{mg}$ spiro-OMeTAD, $28.8 \mu \mathrm{L}$ 4-tert-butylpyridine, $17.5 \mu \mathrm{L}$ of a stock solution of 520 $\mathrm{mg} \mathrm{mL}^{-1}$ lithium bis(trifluoromethylsulphonyl) imide in acetonitrile in $1 \mathrm{~mL}$ chlorobenzene. In the fabrication, the perovskite film and HTM were prepared in a glove box. Finally, $150 \mathrm{~nm} \mathrm{Ag}$ was thermally evaporated onto the HTM layer in vacuum to act as the cathode. The cell area is $0.09 \mathrm{~cm}^{2}$. While moving, the samples were placed in special boxes filled with nitrogen, and the device was stored in cabinet with flowing $\mathrm{N}_{2}$ gas.

\section{Characterization}

$\mathrm{X}$-ray diffraction (XRD) patterns were obtained using D8 advance diffractometer with $\mathrm{Cu} \mathrm{Ka}$ radiation $(40 \mathrm{kV}$ and $40 \mathrm{~mA}$ ) and the scanning rate of $4^{\circ} \mathrm{min}^{-1}$ over the Bragg angle range of $10^{\circ}-80^{\circ}$. Scanning electron microscopy (SEM) analysis was performed on a Hitachi-S-4800 electron microscope. Transmission electron microscopy (TEM) images were acquired with JEOL $200 \mathrm{CX}$ at $200 \mathrm{kV}$. $\mathrm{X}$-ray photoelectron spectroscopy (XPS) was conducted using an ESCALAB250 spectrometer equipped with a monochromatized $\mathrm{Al} \mathrm{Ka}$ source. The charge effect was calibrated using the binding energy of C $1 \mathrm{~s}(284.6 \mathrm{eV})$ to reduce its effect. Atomic-force microscopy (AFM) images were recorded using asylum research MFP-3D in the AC mode under ambient conditions. Additionally, the thicknesses of the thin films were estimated using AFM step analysis. Ultraviolet-visible (UV-vis) transmittance was recorded with a Shimadzu UV-2550 (300-600 nm: xenon lamp, $300 \mathrm{~W}$; 600-900 nm: tungsten-halogen lamp, 150 W), and TRPL spectra was measured by Fls- 800 spectrometers. The photocurrent-voltage $(J-V)$ characteristics of the solar cells were measured using a Keithley 2400 source under illumination of a simulated sunlight (AM1.5, 100 $\mathrm{mW} \mathrm{cm}^{-2}$ ) provided by a Newport 69907 solar simulator with an AM 1.5 filter. Light intensity was adjusted with an NREL-calibrated Si solar cell using a KG-2 filter for approximating 1 sun light intensity. While measuring the current and voltage, the cell was covered by a black mask with an aperture that was close to the active device area. The incident photon-to-current efficiency (IPCE) was measured in DC mode with a $1 / 4 \mathrm{~m}$ double monochromator (Crowntech DK242), a multi-meter (Keithley 2000), and two light sources depending on the wavelength range required (300-600 nm xenon lamp, $300 \mathrm{~W}$; 600-900 nm: tungsten-halogen lamp, $150 \mathrm{~W}$ ). The monochromatic light intensity for IPCE spectra efficiency was calibrated using a reference silicon photodiode. All the measurements of the solar cells were performed under ambient atmosphere at room temperature without encapsulation.

The optimization of the perovskite solar cell device architecture can be simply illustrated by model calculation of the so-called IPCE. This quantity provides the number of electrons generated in a solar cell per one incident photon with the Equation (1)

$$
\mathrm{IPCE}=\frac{i_{\mathrm{ph}} h c}{P e \lambda},
$$

where $i_{\text {ph }}$ is the photocurrent density, $h$ is Planck's constant, $\lambda$ is the photon wavelength, $c$ is the velocity of light, $P$ is the incident light power density, and $e$ is the electron charge.

The short circuit photocurrent density for perovskite solar cell illuminated by solar light, $J_{s c}$, is given by the sum Equation (2) of individual contributions from IPCEs, integrated over the whole solar spectrum

$$
J_{s c}=\frac{\int_{\lambda_{1}}^{\lambda_{2}} \operatorname{IPCE}(\lambda) \cdot P_{\text {sun }}(\lambda) \mathrm{d} \lambda}{A},
$$

where $P_{\text {sun }}(\lambda)$ is the solar power density at the wavelength $\lambda . A$ is the area of perovskite solar cell.

\section{RESULTS AND DISCUSSION}

The well-defined and uniform size of $\mathrm{SnO}_{2}$ nanoparticles, 
with an average diameter of $2-5 \mathrm{~nm}$ are revealed by the high-resolution TEM (HR-TEM) in Fig. 2a and Fig. S1a. The Laue electron diffraction patterns in Fig. 2a and Fig. S1b show the polycrystalline nature of $\mathrm{SnO}_{2}$ film and the well-ordered $\mathrm{SnO}_{2}$ crystals, as judged from dominant (110) and (101) facets. The XRD pattern of the $\mathrm{SnO}_{2}$ nanocrystals is given in Fig. 2b. Each diffraction line is assigned to the tetragonal rutile crystalline phase of $\mathrm{SnO}_{2}$ [33]. All of the peaks matched reasonably well with the standard pattern in JCPDS No.21-1250. The diffraction peaks at positions $26.57^{\circ}, 33.87^{\circ}, 37.94^{\circ}, 51.75^{\circ}, 57.82^{\circ}, 61.87^{\circ}, 65.96^{\circ}$, $71.28^{\circ}, 78.69^{\circ}$ correspond to (110), (101), (200), (211), (002), (310), (301), (202) and (321) as indicated by Fig. $2 \mathrm{~b}$, which are consistent with the selective area electron diffraction (SAED) image of $\mathrm{SnO}_{2}$ nanocrystals in Fig. 2a. The average crystallite size of $3.5 \mathrm{~nm}$ is calculated from XRD patterns using the Scherrer formula, in accordance with the result from TEM image [34].

In order to further characterize the composition of $\mathrm{SnO}_{2}$ films and the atomic valence states of $\mathrm{SnO}_{2}$, especially of $\mathrm{Sn}$, core level XPS spectrum of Sn $3 d$ is shown in Fig. 2c, and the full XPS spectrum survey is given in Fig. S2a, showing the presence of $\mathrm{O}$ and $\mathrm{Sn}$. The binding energies of 487 and $495 \mathrm{eV}$ in Fig. $2 c$ correspond to the $S n 3 d_{5 / 2}$ and Sn $3 d_{3 / 2}$ peaks, respectively, confirming the formation of pure $\mathrm{SnO}_{2}$ with the appearance of $\mathrm{Sn}^{4+}$ peaks $[22,29]$. The main binding energy of $531 \mathrm{eV}$ in Fig. S2b is attributed to the $\mathrm{O} 1 \mathrm{~s}$, which is the $\mathrm{O}^{2-}$ state in $\mathrm{SnO}_{2}$. Fig. S2c shows that there is no residual $\mathrm{Cl}$ observed in $\mathrm{SnO}_{2}$ films. From the TEM, XRD and XPS data, we can see that the $\mathrm{SnO}_{2}$ nanocrystals with uniform nanoparticle size and well-defined crystallinity have been fabricated successfully, ideal for the compact $\mathrm{SnO}_{2}$ ESL in PSCs.

To investigate the surface morphology of $\mathrm{SnO}_{2}$ film, SEM and AFM images are shown in Fig. 3. The surface morphology of $\mathrm{SnO}_{2}$ films as observed from the SEM in Fig. 3a and AFM micrograph in Fig. $3 \mathrm{~b}$ and Fig. $\mathrm{S} 3$ show that the grains are uniformly distributed within the scanning area, and the film is smooth with a root mean square (RMS) surface roughness of $\sim 14.9 \mathrm{~nm}$ in an area of $2 \mu \mathrm{m} \times 2 \mu \mathrm{m}$, smaller than $25.76 \mathrm{~nm}$ reported in high-temperature processed films with large particle size [35]. This surface char-
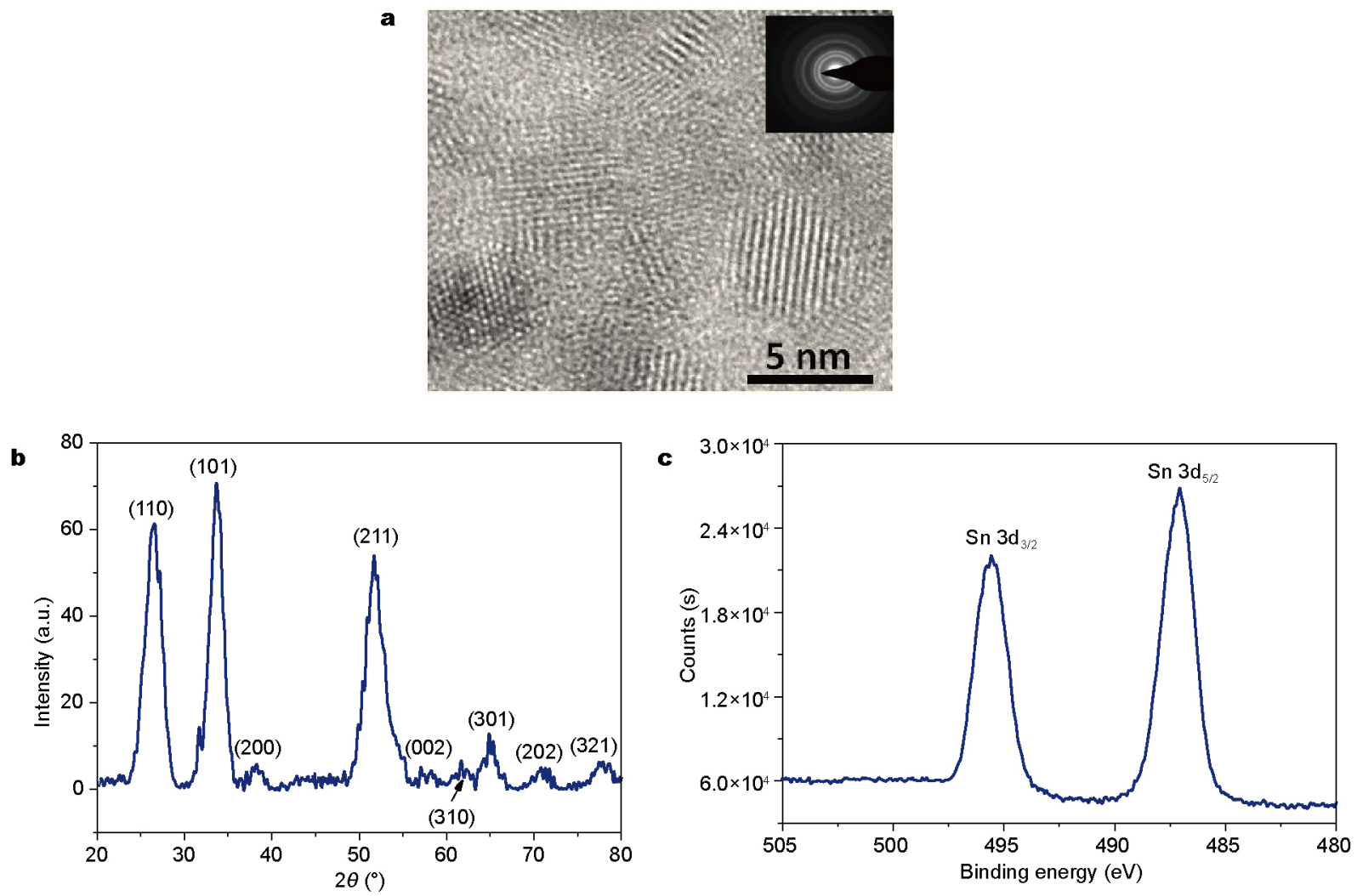

Figure 2 Microstructure of $\mathrm{SnO}_{2}$ nanocrystals. (a) HRTEM image (the inset is SAED image of $\mathrm{SnO}_{2}$ film); (b) XRD pattern of $\mathrm{SnO}_{2}$ powders; and (c) XPS spectra of Sn 3d peaks. 

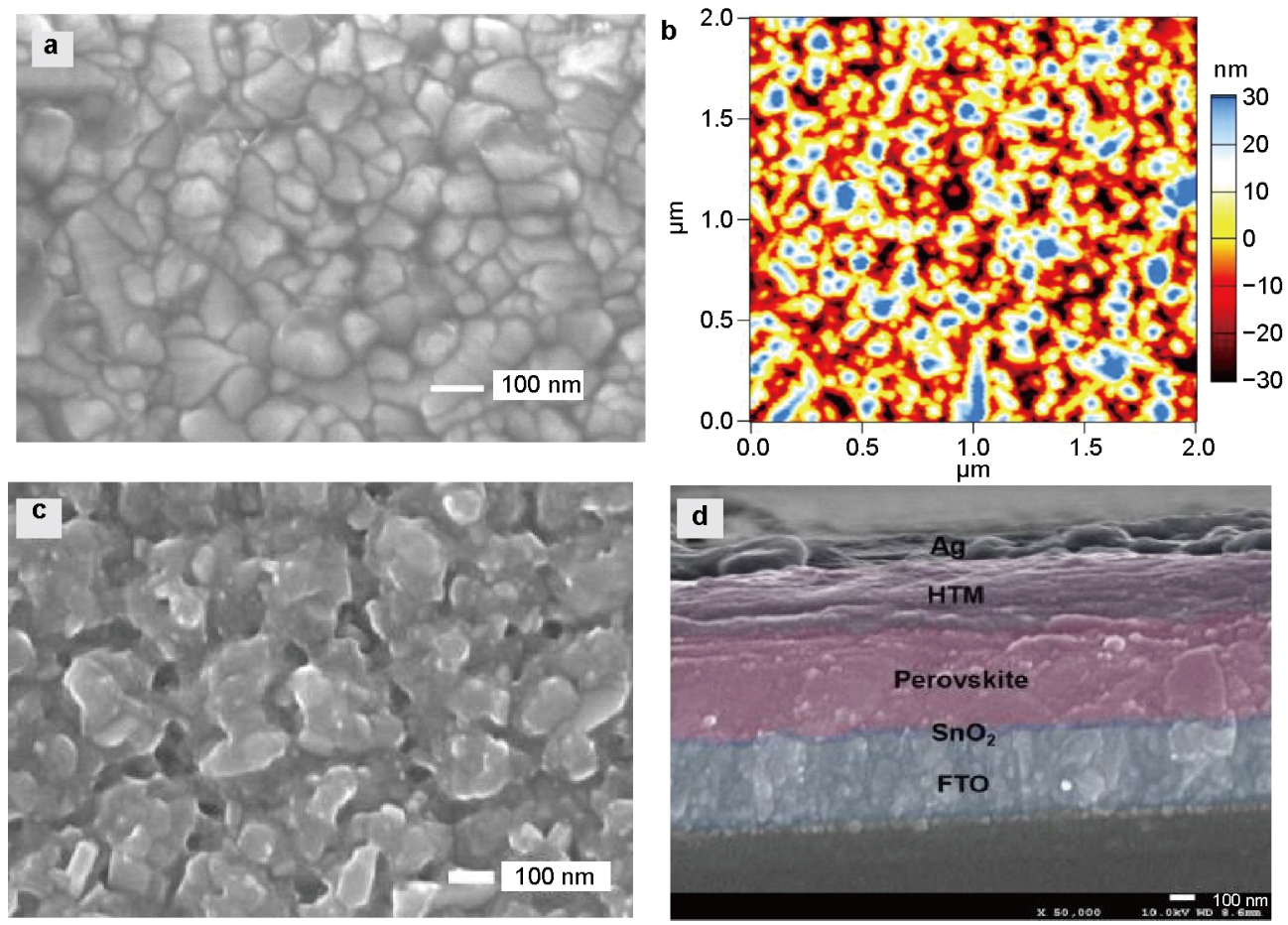

Figure 3 SEM image (a) and AFM height image (b) of $\mathrm{SnO}_{2}$ film; (c) SEM image of perovskite film on $\mathrm{SnO}_{2}$ film; (d) cross-sectional SEM image of the device.

acteristic is important for $\mathrm{SnO}_{2}$ 's applications as ESL. Crosssectional AFM probing was used to measure the thickness of the film, as shown in Fig. S4, which is estimated to be around $10 \mathrm{~nm}$ for $\mathrm{SnO}_{2}$ on FTO substrate [36]. To better illustrate the device structure, $\mathrm{SEM}$ images of $\mathrm{CH}_{3} \mathrm{NH}_{3} \mathrm{PbI}_{3}$ perovskite films on $\mathrm{SnO}_{2}$ and $\mathrm{TiO}_{2}$ film are shown in Fig. $3 \mathrm{c}$ and Fig. S5, and a color-enhanced cross-sectional SEM image is presented in Fig. 3d. The $\mathrm{SnO}_{2}$ films are fully compatible with the growth of $\mathrm{CH}_{3} \mathrm{NH}_{3} \mathrm{PbI}_{3}$ perovskite absorbers, and the $\mathrm{CH}_{3} \mathrm{NH}_{3} \mathrm{PbI}_{3}$ perovskite films have covered the $\mathrm{SnO}_{2}$ and $\mathrm{TiO}_{2}$ film completely with good uniformity.
$\mathrm{TiO}_{2}$ films deposited on the FTO substrates exhibit similar morphologies as $\mathrm{SnO}_{2}$, as shown in Fig. S6, suggesting that our low-temperature spin-coating process is ideal for fabrication of thin ESL with full surface coverage, nanoscale particle size, and uniform crystalline structure in PSCs.

Fig. 4 shows the current-voltage characteristics $(J-V)$ measured under simulated solar AM1.5G irradiation $\left(100 \mathrm{~mW} \mathrm{~cm} \mathrm{~cm}^{-2}\right)$ and in dark for PSCs comprised of FTO/ESL/ $\mathrm{CH}_{3} \mathrm{NH}_{3} \mathrm{PbI}_{3} /$ Spiro-OMETAD/Ag. Typical $J-V$ curves under reverse and forward scan directions for $\mathrm{SnO}_{2}$-based device are shown in Fig. $4 \mathrm{a}$, in which a small
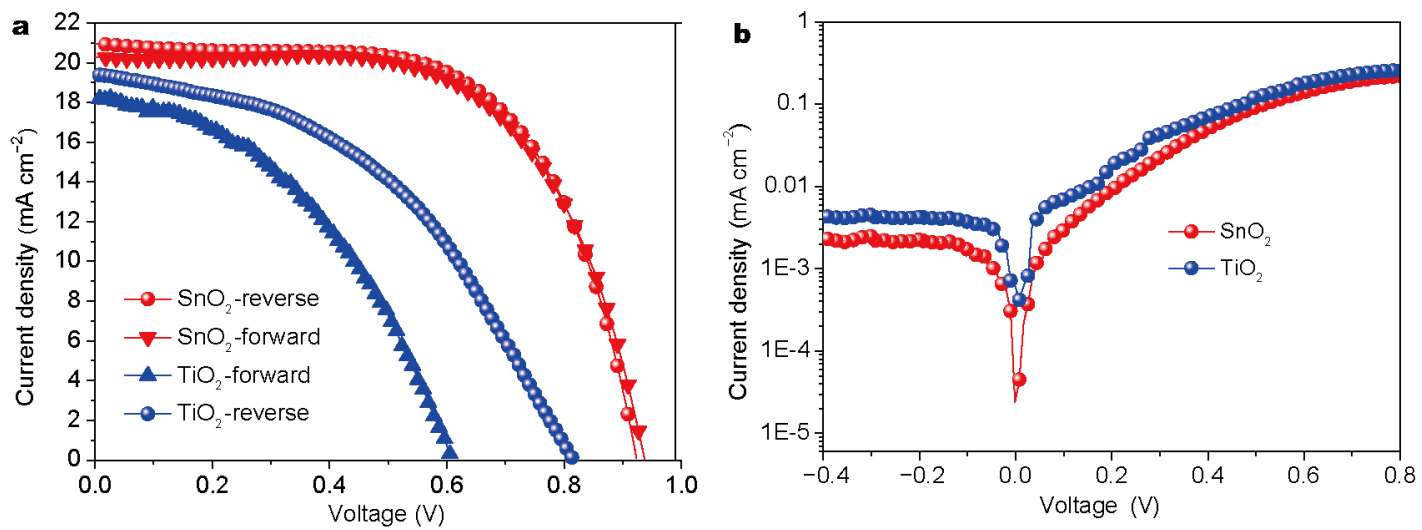

Figure 4 (a) $J$ - $V$ curves of perovskite solar cells with $\mathrm{SnO}_{2}$ and $\mathrm{TiO}_{2} \mathrm{ESL}$; (b) dark current measurements for perovskite solar cells. All $J$ - $V$ curves were measured under $100 \mathrm{~mW} \mathrm{~cm} \mathrm{~cm}^{-2}$ air mass (AM 1.5G) illumination. 
Table 1 Photovoltaic performance parameters of $\mathrm{SnO}_{2}$ - and $\mathrm{TiO}_{2}$-based solar cells with forward and reverse scans

\begin{tabular}{cccc}
\hline Device & $V_{\mathrm{oc}}(\mathrm{V})$ & $J_{\mathrm{sc}}\left(\mathrm{mA} \mathrm{cm}^{-2}\right)$ & FF $(\%)$ \\
\hline $\mathrm{SnO}_{2}$-reverse & $0.91 \pm 0.02$ & $20.73 \pm 0.2$ & $64.26 \pm 0.5$ \\
$\mathrm{SnO}_{2}$-forward & $0.93 \pm 0.02$ & $20.22 \pm 0.2$ & $63.53 \pm 0.5$ \\
$\mathrm{TiO}_{2}$-reverse & $0.81 \pm 0.02$ & $19.36 \pm 0.2$ & $11.92 \pm 0.3$ \\
$\mathrm{TiO}_{2}$-forward & $0.61 \pm 0.02$ & $18.18 \pm 0.2$ & $7.16 \pm 0.3$ \\
\hline
\end{tabular}

hysteresis is observed. The hysteresis is mostly dependent on the device architecture $[8,37,38]$. A reference cell with $\mathrm{TiO}_{2}$ ESL is also presented for comparison, showing much larger hysteresis. The PSCs with $\mathrm{SnO}_{2}$ ESL displayed an open-circuit voltage $\left(V_{\text {oc }}\right)$ of $0.91 \pm 0.02 \mathrm{~V}$, a short circuit current density $\left(J_{\mathrm{sc}}\right)$ of $20.73 \pm 0.2 \mathrm{~mA} \mathrm{~cm}^{-2}$ and a fill factor (FF) of $64.26 \% \pm 0.5 \%$, resulting in a PCE of $12.10 \% \pm 0.3 \%$ in the reverse scan. With $\mathrm{TiO}_{2} \mathrm{ESL}$, the PSCs in the reverse scan show a lower PCE of $7.16 \% \pm 0.3 \%$, with a significant reduction in the average $\mathrm{FF}$ (from $64.26 \%$ to $45.55 \%$ ), $V_{\text {oc }}$ (from 0.91 to $0.81 \mathrm{~V}$ ) and $J_{\text {sc }}$ (from 20.73 to $19.36 \mathrm{~mA}$ $\mathrm{cm}^{-2}$ ). The PSCs with $\mathrm{SnO}_{2}$ ESL exhibit a high $V_{\mathrm{oc}}, J_{\mathrm{sc}}$ and $\mathrm{FF}$ largely due to the effective charge dissociation between $\mathrm{CH}_{3} \mathrm{NH}_{3} \mathrm{PbI}_{3}$ and $\mathrm{SnO}_{2}$, followed by fast electrons transport through $\mathrm{SnO}_{2}$ to the FTO. As a result, the charge recombination in the $\mathrm{SnO}_{2}$-based PSCs could be suppressed much more effectively compared with the $\mathrm{TiO}_{2}$-based PSCs, leading to a rather lower back current density in $\mathrm{SnO}_{2}$-based PSCs, as exhibited by the dark $J$ - $V$ characteristics in Fig. 4 b [39]. Apparently, all the dark current-voltage characteristics display very similar trends, and the saturation current density of the $\mathrm{SnO}_{2}$-based device is lower than that of the $\mathrm{TiO}_{2}$-based cell, thereby resulting in a larger $V_{\text {oc }}[39,40]$. The stability of the perovskite devices with $\mathrm{SnO}_{2}$ as the ESL was tested without encapsulation in air at room temperature (Fig. S7). After $45,000 \mathrm{~s}(12.5 \mathrm{~h})$, the PCE, $J_{\mathrm{sc}}$ and $V_{\mathrm{oc}}$ of $\mathrm{SnO}_{2}$-based solar cell devices were stabilized at about $10 \%$, $18 \mathrm{~mA} \mathrm{~cm}^{-2}$ and $0.9 \mathrm{~V}$, compared with $6 \%, 17 \mathrm{~mA} \mathrm{~cm}^{-2}$ and $0.7 \mathrm{~V}$ of $\mathrm{TiO}_{2}$-based solar cell devices, respectively.

To verify that $\mathrm{SnO}_{2}$ and $\mathrm{TiO}_{2}$ are effective quenching materials for electrons, the steady-state photoluminescence (PL) spectra of perovskite films with these quenchers in the middle of FTO and perovskite layer were measured. As shown in Fig. 5a, compared with the perovskite on glass, the PL peak decrease for both $\mathrm{SnO}_{2}$ and $\mathrm{TiO}_{2}$, whereas the $\mathrm{SnO}_{2}$ shows much better quenching efficiency. Electrons or holes are dissociated at the interfaces between $\mathrm{CH}_{3} \mathrm{NH}_{3} \mathrm{PbI}_{3}$ perovskite and the $\mathrm{SnO}_{2}$ or $\mathrm{TiO}_{2}$ quencher, which are then transferred to the quencher and can no longer contribute to PL. In order to extract quantitative analysis on the yield of light induced charge carrier separation, we performed the TRPL measurements in Fig. 5b. Excitons emerged by light excitation of perovskite were extracted into free charge carriers within 1 ps [41]. The hole-carrier through thin $\mathrm{SnO}_{2}$ and $\mathrm{TiO}_{2}$ nanocrystals layer was measured by the PL decay. The PL decay at the interface of $\mathrm{CH}_{3} \mathrm{NH}_{3} \mathrm{PbI}_{3}$ perovskite and $\mathrm{SnO}_{2}$ films displays an average time constant of $\tau_{\mathrm{e}}=(5.1 \pm 0.4) \mathrm{ns}$, whereas for the $\mathrm{TiO}_{2}, \tau_{\mathrm{e}}$ is $(5.5 \pm 0.4) \mathrm{ns}$, both of which are shorter than the perovskite layer on glass $(78 \pm 0.5) \mathrm{ns}$, indicating that charge carriers within the $\mathrm{CH}_{3} \mathrm{NH}_{3} \mathrm{PbI}_{3}$ perovskite layer can be dissociated effectively by these inorganic oxides [42]. The shorter exciton (electron hole pair) lifetime observed with $\mathrm{SnO}_{2}$ ESL suggests a faster charge-transfer kinetics, and it is an indicator of lower defect concentration and good crystalline quality $[9,22,43]$. The efficient carrier dissociation in $\mathrm{SnO}_{2}$-based solar cells results from the high carrier mobility or lower conduction band level of $\mathrm{SnO}_{2}$ electron selective layer. This advantage can be regarded as a factor that results in $+1.37 \mathrm{~mA} \mathrm{~cm}{ }^{-2}$ higher $J_{\mathrm{sc}}$ of $\mathrm{SnO}_{2}$ than that of $\mathrm{TiO}_{2}$-based solar cell device.

Fig. $5 \mathrm{c}$, $\mathrm{d}$ show the UV-vis transmission spectra and IPCE for the $\mathrm{SnO}_{2}$ and $\mathrm{TiO}_{2}$ ESL, respectively. Generally, the trends of the IPCE spectra of the $\mathrm{CH}_{3} \mathrm{NH}_{3} \mathrm{PbI}_{3}$ devices in Fig. 5d agree with that of the UV-vis transmission spectrum in Fig. $5 \mathrm{c}$ : the shapes of the IPCE spectrum match excellently with that of the UV-vis transmission spectrum, and the IPCE is enlarged upon improving the light transmission intensity. The onset of the UV-vis transmittance at $\sim 340 \mathrm{~nm}$ for $\mathrm{SnO}_{2}$ corresponds to the band gap of $3.64 \mathrm{eV}$. For $\mathrm{TiO}_{2}$ nanoparticles, the UV-vis absorption band at 370 $\mathrm{nm}$ corresponds to the band gap $3.2 \mathrm{eV}$. The IPCE spectrum with $\mathrm{SnO}_{2}$ ESL shows a broad peak value of about $90 \%$, while $\mathrm{TiO}_{2}$ as the ESL displays a broad peak value below $80 \%$ in the range from 400 to $780 \mathrm{~nm}$. The photocurrents of $21.0 \mathrm{~mA} \mathrm{~cm}^{-2}$ integrated from area of the $\mathrm{SnO}_{2}$-based IPCE spectra is consistent with the $J_{\mathrm{sc}}$ values gained from the $J-V$. The onset of IPCE photocurrent is at $\sim 780 \mathrm{~nm}$, consistent with the reported band gap [6,44]. The ultrathin $\mathrm{SnO}_{2}$ ESL can put $\sim 80 \%$ light through, and this potentially increases 

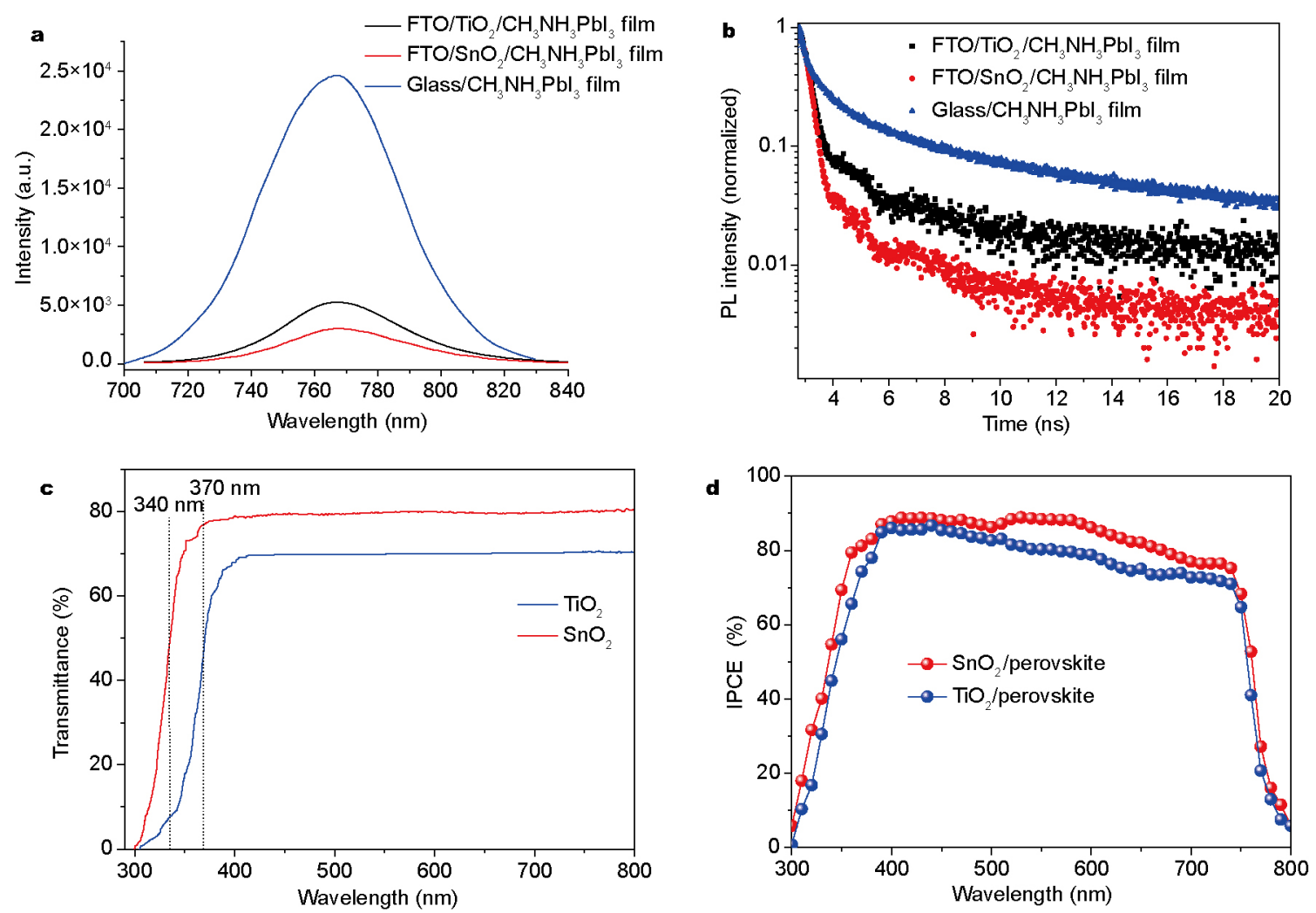

Figure 5 (a) Steady-state PL of perovskite deposited on $\mathrm{SnO}_{2}$ film, $\mathrm{TiO}_{2}$ film and glass; (b) TRPL (excitation wavelength at $507 \mathrm{~nm}$ ) of the perovskites on $\mathrm{SnO}_{2}$ film, $\mathrm{TiO}_{2}$ film and glass; (c) transmission spectra of $\mathrm{TiO}_{2} / \mathrm{FTO}$ and $\mathrm{SnO}_{2} / \mathrm{FTO}$ films; (d) IPCE spectra of perovskite devices with $\mathrm{SnO}_{2}$ and $\mathrm{TiO}_{2}$ as ESL.

the amount of light absorption in perovskite layer above $\mathrm{SnO}_{2}$ ESL. The simple planar structure and the production of such high-performance cells with low-temperature spin-coating of ESL confirm the good potential of $\mathrm{SnO}_{2}$ in photovoltaic applications $[29,45,46]$.

\section{CONCLUSIONS}

The well-crystallized $\mathrm{SnO}_{2}$ ESL is successfully spin-coated on FTO glass at $100^{\circ} \mathrm{C}$ without further high-temperature sintering process. The low-temperature spin-coated $\mathrm{SnO}_{2}$ film displays uniform particle size of $2-5 \mathrm{~nm}$, ultrathin thickness of $10 \mathrm{~nm}$, complete surface coverage and fast charge-transfer kinetics of $5.1 \mathrm{~ns}$, and the resulting efficiency of $12.10 \%$ is notable compared with $7.16 \%$ in $\mathrm{TiO}_{2}$ based PSCs. The stabilized efficiency of $\mathrm{SnO}_{2}$-based PSCs is ascribed to the crystallized compact/thin $\mathrm{SnO}_{2}$ ESL suppressing the electron recombination. We believe that this sintering-free nanocrystalline $\mathrm{SnO}_{2}$ ESL film will find applications in large-scale and low-cost PSCs.

Received 19 November 2016; accepted 26 December 2016; published online 6 February 2017
1 Kojima A, Teshima K, Shirai Y, et al. Organometal halide perovskites as visible-light sensitizers for photovoltaic cells. J Am Chem Soc, 2009, 131: 6050-6051

2 Park M, Kim JY, Son HJ, et al. Low-temperature solution-processed Li-doped $\mathrm{SnO}_{2}$ as an effective electron transporting layer for high-performance flexible and wearable perovskite solar cells. Nano Energy, 2016, 26: 208-215

3 Lee MM, Teuscher J, Miyasaka T, et al. Efficient hybrid solar cells based on meso-superstructured organometal halide perovskites. Science, 2012, 338: 643-647

4 Burschka J, Pellet N, Moon SJ, et al. Sequential deposition as a route to high-performance perovskite-sensitized solar cells. Nature, 2013, 499: 316-319

5 Chen W, Wu Y, Yue Y, et al. Efficient and stable large-area perovskite solar cells with inorganic charge extraction layers. Science, 2015, 350: 944-948

6 Zhou H, Chen Q, Li G, et al. Interface engineering of highly efficient perovskite solar cells. Science, 2014, 345: 542-546

7 Zhao Z, Chen X, Wu H, et al. Probing the photovoltage and photocurrent in perovskite solar cells with nanoscale resolution. Adv Funct Mater, 2016, 26: 3048-3058

8 Yang WS, Noh JH, Jeon NJ, et al. High-performance photovoltaic perovskite layers fabricated through intramolecular exchange. Science, 2015, 348: 1234-1237

9 Wang Q, Chen H, Liu G, et al. Control of organic-inorganic halide perovskites in solid-state solar cells: a perspective. Sci Bull, 2015, 60: 405-418

10 Ke W, Fang G, Wan J, et al. Efficient hole-blocking layer-free planar 
halide perovskite thin-film solar cells. Nat Commun, 2015, 6: 6700

11 Wojciechowski K, Saliba M, Leijtens T, et al. Sub- $150^{\circ} \mathrm{C}$ processed meso-superstructured perovskite solar cells with enhanced efficiency. Energy Environ Sci, 2014, 7: 1142-1147

12 Zhao JJ, Wang P, Liu ZH, et al. Controlled reaction for improved $\mathrm{CH}_{3} \mathrm{NH}_{3} \mathrm{PbI}_{3}$ transition in perovskite solar cells. Dalton Trans, 2015, 44: 17841-17849

13 Zhong D, Cai B, Wang X, et al. Synthesis of oriented $\mathrm{TiO}_{2}$ nanocones with fast charge transfer for perovskite solar cells. Nano Energy, 2015, 11: 409-418

14 Zhao J, Wang P, Wei L, et al. Efficient charge-transport in hybrid lead iodide perovskite solar cells. Dalton Trans, 2015, 44: 16914-16922

15 Liu D, Kelly TL. Perovskite solar cells with a planar heterojunction structure prepared using room-temperature solution processing techniques. Nat Photon, 2013, 8: 133-138

16 Gonzalez-Pedro V, Juarez-Perez EJ, Arsyad WS, et al. General working principles of $\mathrm{CH}_{3} \mathrm{NH}_{3} \mathrm{PbX}_{3}$ perovskite solar cells. Nano Lett, 2014, 14: 888-893

$17 \mathrm{Xu} \mathrm{X}$, Zhang H, Shi J, et al. Highly efficient planar perovskite solar cells with $\mathrm{a} \mathrm{TiO}_{2} / \mathrm{ZnO}$ electron transport bilayer. J Mater Chem A, 2015, 3: 19288-19293

18 Son DY, Bae KH, Kim HS, et al. Effects of seed layer on growth of $\mathrm{ZnO}$ nanorod and performance of perovskite solar cell. J Phys Chem C, 2015, 119: 10321-10328

19 Han GS, Chung HS, Kim DH, et al. Epitaxial 1D electron transport layers for high-performance perovskite solar cells. Nanoscale, 2015, 7: 15284-15290

$20 \mathrm{Li} \mathrm{Y,} \mathrm{Zhu} \mathrm{J,} \mathrm{Huang} \mathrm{Y,} \mathrm{et} \mathrm{al.} \mathrm{Mesoporous} \mathrm{SnO}_{2}$ nanoparticle films as electron-transporting material in perovskite solar cells. RSC Adv, 2015, 5: 28424-28429

21 Zhu Z, Zheng X, Bai Y, et al. Mesoporous $\mathrm{SnO}_{2}$ single crystals as an effective electron collector for perovskite solar cells. Phys Chem Chem Phys, 2015, 17: 18265-18268

22 Correa Baena JP, Steier L, Tress W, et al. Highly efficient planar perovskite solar cells through band alignment engineering. Energy Environ Sci, 2015, 8: 2928-2934

23 Grätzel M. Photoelectrochemical cells. Nature, 2001, 414: 338-344

24 Snaith HJ, Ducati C. $\mathrm{SnO}_{2}$-based dye-sensitized hybrid solar cells exhibiting near unity absorbed photon-to-electron conversion efficiency. Nano Lett, 2010, 10: 1259-1265

25 Tiwana P, Docampo P, Johnston MB, et al. Electron mobility and injection dynamics in mesoporous $\mathrm{ZnO}, \mathrm{SnO}_{2}$, and $\mathrm{TiO}_{2}$ films used in dye-sensitized solar cells. ACS Nano, 2011, 5: 5158-5166

26 Sadoughi G, Sivaram V, Gunning R, et al. Enhanced electronic contacts in $\mathrm{SnO}_{2}$-dye-P3HT based solid state dye sensitized solar cells. Phys Chem Chem Phys, 2013, 15: 2075-2080

27 Kranz L, Abate A, Feurer T, et al. High-efficiency polycrystalline thin film tandem solar cells. J Phys Chem Lett, 2015, 6: 2676-2681

28 Dong Q, Shi Y, Wang K, et al. Insight into perovskite solar cells based on $\mathrm{SnO}_{2}$ compact electron-selective layer. J Phys Chem C, 2015, 119: 10212-10217

29 Ke W, Fang G, Liu Q, et al. Low-temperature solution-processed tin oxide as an alternative electron transporting layer for efficient perovskite solar cells. J Am Chem Soc, 2015, 137: 6730-6733

30 Song J, Zheng E, Bian J, et al. Low-temperature $\mathrm{SnO}_{2}$-based electron selective contact for efficient and stable perovskite solar cells. J Mater Chem A, 2015, 3: 10837-10844

31 Liu X, Tsai KW, Zhu Z, et al. A low-temperature, solution processable tin oxide electron-transporting layer prepared by the dual-fuel combustion method for efficient perovskite solar cells. Adv Mater Interfaces, 2016, 3: 1600122
32 Zhao J, Zhang J, Wang W, et al. Facile synthesis of CuInGaS 2 quantum dot nanoparticles for bilayer-sensitized solar cells. Dalton Trans, 2014, 43: 16588-16592

33 Gu F, Fen Wang S, Feng Song C, et al. Synthesis and luminescence properties of $\mathrm{SnO}_{2}$ nanoparticles. Chem Phys Lett, 2003, 372: 451-454

34 Patterson AL. The Scherrer formula for X-ray particle size determination. Phys Rev, 1939, 56: 978-982

35 Khan AF, Mehmood M, Rana AM, et al. Effect of annealing on electrical resistivity of rf-magnetron sputtered nanostructured $\mathrm{SnO}_{2}$ thin films. Appl Surface Sci, 2009, 255: 8562-8565

36 Chen Z, Lin YM, Rooks MJ, et al. Graphene nano-ribbon electronics. Physica E, 2007, 40: 228-232

37 Snaith HJ, Abate A, Ball JM, et al. Anomalous hysteresis in perovskite solar cells. J Phys Chem Lett, 2014, 5: 1511-1515

38 Frost JM, Butler KT, Brivio F, et al. Atomistic origins of high-performance in hybrid halide perovskite solar cells. Nano Lett, 2014 14: 2584-2590

39 Cai B, Xing Y, Yang Z, et al. High performance hybrid solar cells sensitized by organolead halide perovskites. Energy Environ Sci, 2013, 6: 1480-1485

$40 \mathrm{He}$ Z, Xiao B, Liu F, et al. Single-junction polymer solar cells with high efficiency and photovoltage. Nat Photon, 2015, 9: 174-179

41 Ponseca Jr CS, Savenije TJ, Abdellah M, et al. Organometal halide perovskite solar cell materials rationalized: ultrafast charge generation, high and microsecond-long balanced mobilities, and slow recombination. J Am Chem Soc, 2014, 136: 5189-5192

42 You J, Meng L, Song TB, et al. Improved air stability of perovskite solar cells via solution-processed metal oxide transport layers. Nat Nanotech, 2015, 11: 75-81

43 Mei A, Li X, Liu L, et al. A hole-conductor-free, fully printable mesoscopic perovskite solar cell with high stability. Science, 2014, 345: 295-298

44 Docampo P, Ball JM, Darwich M, et al. Efficient organometal trihalide perovskite planar-heterojunction solar cells on flexible polymer substrates. Nat Commun, 2013, 4: 2761

45 Seo J, Park S, Chan Kim Y, et al. Benefits of very thin PCBM and LiF layers for solution-processed p-i-n perovskite solar cells. Energy Environ Sci, 2014, 7: 2642-2646

46 Edri E, Kirmayer S, Henning A, et al. Why lead methylammonium tri-iodide perovskite-based solar cells require a mesoporous electron transporting scaffold (but not necessarily a hole conductor)? Nano Lett, 2014, 14: 1000-1004

Acknowledgments This work was supported by the National Key Research and Development Program of China (2016YFA0201001), National Natural Science Foundation of China (11627801, 51102172), Science and Technology Plan of Shenzhen City (JCYJ20160331191436180), Natural Science Foundation for Outstanding Young Researcher in Hebei Province (E2016210093), the Key Program of Educational Commission of Hebei Province of China (ZD2016022), the Youth Top-notch Talents Supporting Plan of Hebei Province, Hebei Provincial Key Laboratory of Traffic Engineering materials and Hebei Key Discipline Construction Project.

Author contributions Zhao J and Wei $\mathrm{L}$ designed and engineered the samples; Wei L and Jia C performed the experiments; Wang P and Liu Z performed the structural and $J-V$ performance measurement; Li J and Liu J performed the data analysis; Zhao J wrote the paper with support from Li J. All authors contributed to the general discussion.

Conflict of interest The author declare that they have no conflict of interest. 

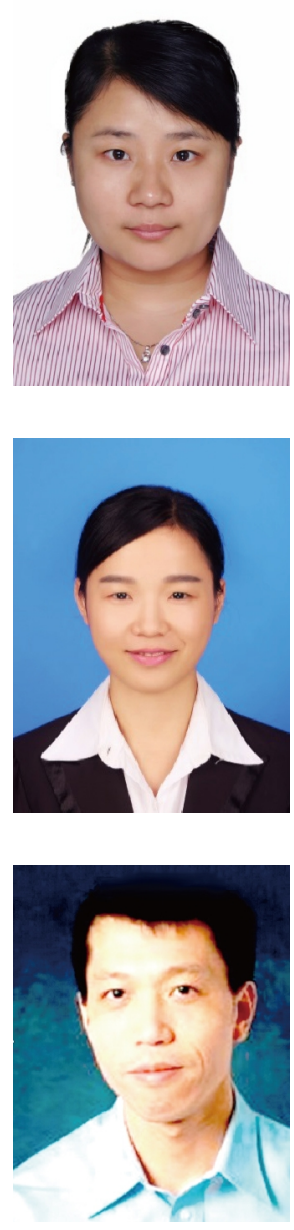

Jinjin Zhao received her BE degree in materials science and engineering from Hebei University of Science and Technology in 2005, and her PhD in materials physics and chemistry from Shanghai Institute of Ceramics, Chinese Academy of Sciences in 2010. She did her visiting doctoral studies at Max Plank Institute of Colloids and Interfaces, Germany, from October 2007 to October 2008, and visiting scholar at the University of Washington from August 2015 to August 2016. She held faculty appointment in Shijiazhuang Tiedao University. Her research interest is probing multi-physical couplings in perovskite solar cells based on dynamic photovoltaic thermal strain.

Liyu Wei received her BE degree in materials science and engineering from Shijiazhuang Tiedao University in 2014, and now she is a master candidate at the School of Materials Science and Engineering from Shijiazhuang Tiedao University. Her research interest is the organometallic halide perovskite solar cells.
Jiangyu Li received his BE degree in materials science and engineering from Tsinghua University in 1994, and PhD in mechanical engineering from the University of Colorado, Boulder in 1998. He did his postdoctoral studies at the University of California, San Diego and California Institute of Technology, and held faculty appointments at the University of Nebraska, Lincoln, and the University of Washington. His research interests include mechanics and physics of multifunctional materials through continuum modeling and simulations and scanning probe microscopy investigations.

\section{基于氧化锡纳米晶的低温电子传输层型钻铁矿太阳电池的研究}

赵晋津 ${ }^{1,2,3 \dagger^{*}}$, 魏丽玉 ${ }^{1 \dagger}$, 刘金喜 ${ }^{1}$, 王鹏 ${ }^{1}$, 刘正浩 ${ }^{1,3}$, 贾春媚 ${ }^{1}$, 李江宇 ${ }^{2,3 *}$

摘要 高效的电子选择层对提高有机金属卤化物基钻钛矿太阳电池的能量转换效率起着至关重要的作用. 本文采用低温 $100^{\circ} \mathrm{C}$ 旋转涂膜和无 后续高温烧结的方法制备了高结晶度的纳米氧化锡薄膜, 利用瞬态时间分辨荧光光谱测试对 $\mathrm{SnO}_{2} / \mathrm{CH}_{3} \mathrm{NH}_{3} \mathrm{PbI}_{3}$ 薄膜进行分析发现, 这种低温 氧化锡薄膜与相同条件下制备的低温氧化钛薄膜相比, 具有更高的苂光淬灭和电子抽取能力. 电流-电压曲线表明, 低温氧化锡基钙钛矿太 阳电池具有优异的光电转换性能, 其开路电压为 $0.91 \mathrm{~V}$, 短路电流密度为 $20.73 \mathrm{~mA} \mathrm{~cm}^{-2}$, 填充因子为 $64.25 \%$, 其器件光电转换效率达到 $12.10 \%$, 高于低温二氧化钛基器件的光电转换效率 $7.16 \%$. 上述无高温烧结的旋转涂膜方法为制备低温大面积钻钛矿太阳电池提供了一种研究思路. 